\title{
Gene Editing, Gene Therapy, and Cell Xenotransplantation: Cell Transplantation Across Species
}

\author{
Nizar I. Mourad ${ }^{1} \cdot$ Pierre Gianello $^{1}$
}

Published online: 21 July 2017

(C) The Author(s) 2017. This article is an open access publication, Corrected publication August/2017

\begin{abstract}
Purpose of Review Cell xenotransplantation has the potential to provide a safe, ethically acceptable, unlimited source for cell replacement therapies. This review focuses on genetic modification strategies aimed to overcome remaining hurdles standing in the way of clinical porcine islet transplantation and to develop neural cell xenotransplantation.

Recent Findings In addition to previously described genetic modifications aimed to mitigate hyperacute rejection, instant blood-mediated inflammatory reaction, and cell-mediated rejection, new data showing the possibility of increasing porcine islet insulin secretion by transgenesis is an interesting addition to the array of genetically modified pigs available for xenotransplantation. Moreover, combining multiple modifications is possible today thanks to new, improved genomic editing tools. Summary Genetic modification of large animals, pigs in particular, has come a long way during the last decade. These modifications can help minimize immunological and physiological incompatibilities between porcine and human cells, thus allowing for better tolerance and function of xenocells.
\end{abstract}

Keywords Xenotransplantation · Genetic modification · Pig · Pancreatic islets $\cdot$ Diabetes $\cdot$ Neural transplantation

The original version of this article was revised: a modification has been made to the caption of Figure 1. The correct caption of Figure 1 can also be found in the erratum for this article.

This article is part of the Topical Collection on Cellular Transplants

Pierre Gianello

Pierre.Gianello@uclouvain.be

$1 \quad$ Pôle de chirurgie expérimentale et transplantation, Université catholique de Louvain, SSS/IREC/CHEX, Avenue Hippocrate, 55 Bte B1.55.04, 1200 Brussels, Belgium

\section{Introduction}

Cell replacement therapies represent innovative alternative treatments offering the promise of long-lasting restoration or amelioration of disrupted cellular functions rather than temporary alleviation of clinical symptoms necessitating life-long medication. Patients suffering from degenerative and autoimmune diseases could benefit from such treatments. In particular, pancreatic islet allotransplantation for the treatment of type I diabetes became a clinical reality thanks to great advances in islet isolation and preservation and to less aggressive immunosuppression. Transplantation of other cell types such as hepatocytes, bone marrow, or umbilical cord stem cells is also used in the clinic today while neural cell transplantation which could represent a significant step forward in the treatment of neurodegenerative disorders is still in an early development stage. However, and regardless of tissue-specific considerations and difficulties, a common major obstacle standing in the way of wide-spread use of cell transplantation is the lack of human donors, therefore opening the door for the use of alternative sources of cells from other species. In this context, pigs emerged as suitable candidates for providing xenocells due to anatomical and physiological similarities with humans. The possibility of genetically modifying donor pigs to mitigate the host immune reaction to xenografted cells and to adapt their function to human physiology when needed will definitely accelerate the transition of cell xenotransplantation from the bench to the clinic.

\section{Porcine Pancreatic Islet Xenotransplantation}

The rationale behind using porcine pancreatic islets to treat type I diabetes in humans stems from the similarity between porcine and human insulin and the possibility to isolate large 
amounts of islets from a reasonable number of donors [1]. The diabetic non-human primate model has been used extensively to show the efficacy of transplanted adult and neonatal porcine islets with variable degrees of success in a number of preclinical studies as reviewed here [1-3]. Naturally, preserving implanted islets from the host immune response was central in most of these studies. Once this primordial step has been achieved by means of immunosuppression, encapsulation, genetic modification of donors, or a combination of these strategies, the efficacy of porcine islet transplantation is evaluated by looking for signs of diabetes alleviation and by verifying secretory function of grafted tissue. Moreover, host testing for possible porcine pathogens is undertaken to demonstrate biosafety of islet xenotransplantation. With regard to all of these factors that will determine the outcome of pig islet transplantation in preclinical and clinical trials, genetic modification of donors is set to become an unavoidable step.

\section{Modification of Donor Pigs to Improve Insulin Secretion}

Although porcine insulin differs from its human counterpart by a single amino acid and despite similar islet insulin contents in adult porcine and human islets (616 and $725 \mu \mathrm{U} / \mathrm{IEQ}$, respectively), there exist considerable differences between the two with regard to their cell composition and most importantly their physiology. Porcine islets contain fewer $\alpha$-cells $(8 \%)$ compared to human islets (30\%) [4] and most of these cells are further lost during isolation due to their peripheral localization within porcine islets. From a functional point of view, porcine islets respond to glucose stimulation with a 2-3-fold increase of insulin secretion whereas human islets show a 10 12 -fold increase in response to a similar stimulation [5•]. This particularity of porcine beta cells probably explains the need to transplant a large number of islets (up to $50,000 \mathrm{IEQ} / \mathrm{kg}$ receiver body weight) $[6,7]$ for the graft to produce physiologically relevant amounts of insulin. We and others $[3,8 \bullet]$ believe that neonatal pigs represent the most realistic source of islets for xenotransplantation in a clinical setting. Neonatal pig islets are technically and logistically easier to isolate compared to islets from adult pigs. However, these islets are not completely matured and their insulin content and secretion are lower than their adult counterparts [5•]. On the other hand, they have been shown to undergo further maturation in vitro (personal observation) and in vivo after transplantation [9]. Surprisingly, there has been very little effort made to study porcine islet physiology in order to understand the mechanisms behind this low secretory activity of porcine islets both in vivo and in vitro. During an intravenous glucose tolerance test (IVGTT), pig glycemia quickly peaks $1-3$ min following glucose injection then gradually returns to pre-stimulatory levels over a period of $90 \mathrm{~min}$ (Fig. 1a). Plasma insulin measurement over the same period shows a delayed lingering increase that continues up to the 90-min mark (Fig. 1a). In comparison, there is a sevenfold increase of insulinemia
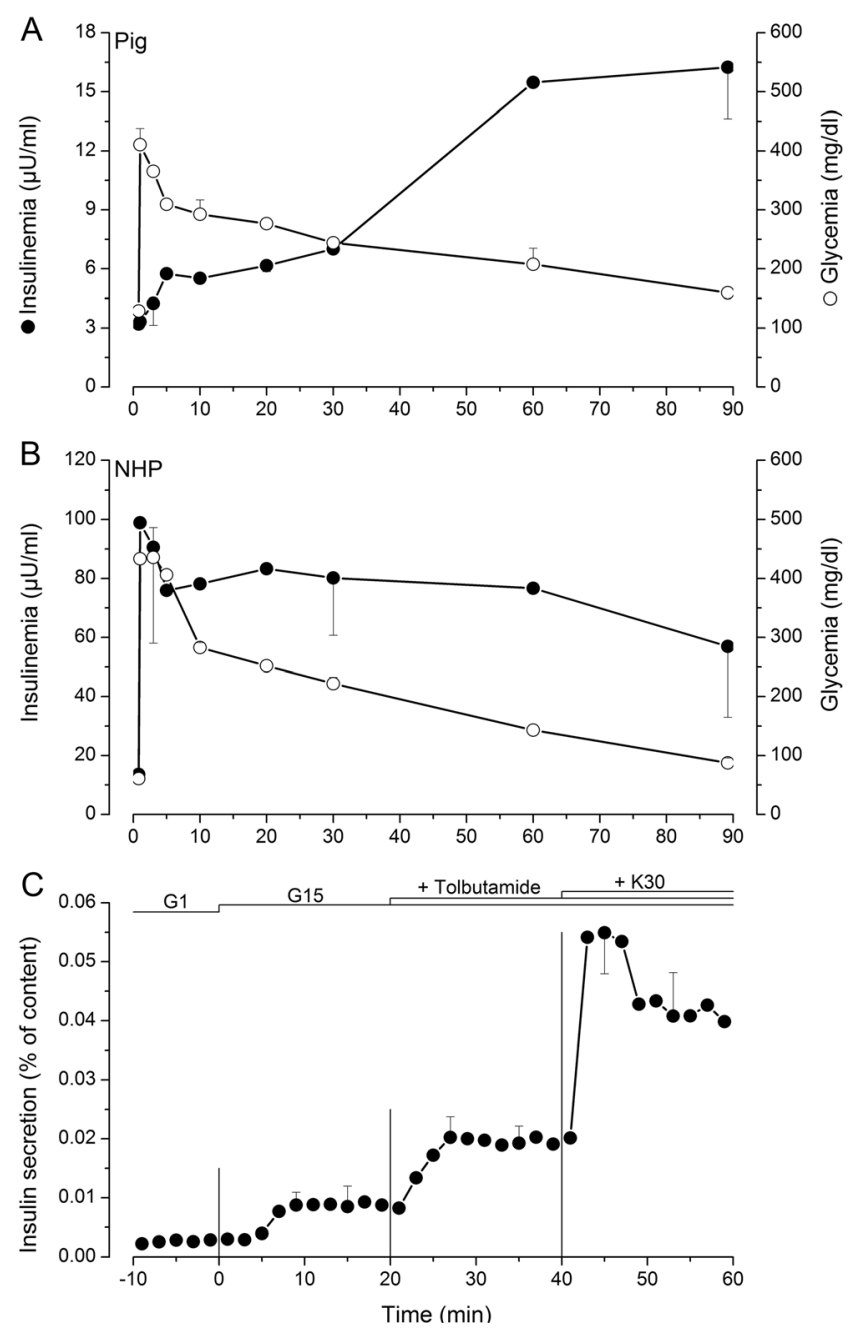

Fig. 1 In vivo and in vitro insulin secretion from porcine islets. a, b Glucose $(\circ)$ and insulin $(\bullet)$ were measured in plasma after intravenous glucose challenge $(0.5 \mathrm{mg} / \mathrm{kg})$ in piglets (a) and non-human primates $(N H P ; \mathbf{b})$. c In vitro insulin secretion from perifused piglet islets exposed to $1 \mathrm{mM}$ glucose $(G l)$ then stimulated with $15 \mathrm{mM}$ glucose $(G 15)$. Potassium channel blocker, tolbutamide $(500 \mu \mathrm{M})$, then $30 \mathrm{mM}$ $\mathrm{KCl}(K 30)$ were added to the perifusion medium as indicated on top of the figure. Values are means \pm SEM from $n=3-5$ intravenous glucose tolerance tests (IVGTTS) and $n=4$ different preparations for islet perifusions

within $3 \mathrm{~min}$ of glucose injection in macaques (Fig. 1b). In vitro perifusion experiments corroborate in vivo data as $15 \mathrm{mM}$ glucose only causes a threefold increase of insulin secretion. As shown in Fig. 1c, porcine islets respond to stimulation with a sulfonylurea (tolbutamide) and secretion is further increased upon depolarization with $30 \mathrm{mM} \mathrm{KCl}$ indicating functional stimulus-secretion coupling in their beta cells. Key cell membrane receptors involved in these pathways such as sulfonylurea receptor (SUR1) and glucagon-like peptide-1 receptor (GLP1R) were shown to be expressed in pig islets [10]. In a recently published study, we showed that genetic modification of pig beta cells can be targeted to increase glucose-stimulated insulin secretion by activating key 
pathways known to regulate insulin secretion in mouse [11, 12] and human [13] islets. Transgenic expression of a DPPV (dipeptidyl peptidase V)-resistant form of GLP-1 (glucagonlike peptide-1) and of a constitutively activated form of a type3 muscarinic receptor (M3R) using an adenoviral vector allowed a significant fourfold amplification of glucosestimulated insulin secretion from both adult and neonatal perifused pig islets [5•]. Pathways and effectors involved in the effects of GLP-1 and muscarinic activation on beta cells are identified and mainly depend on cAMP-dependent activation of protein kinase A (PKA) and exchange protein directly activated by cAMP (Epac2) as well as a rise of cytosolic calcium and protein kinase $\mathrm{C}$ (PKC) activation (Fig. 2) as described previously $[14,15]$. By genetically modifying these two pathways, we could obtain porcine islets that secrete as much insulin as human islets at least in vitro [5•]. Transgenic local production of GLP-1 within mouse islet cells in vitro has been previously described. This has been achieved by means of adenoviral-mediated expression of GLP-1 [16] or of prohormone convertase (PC) 1/3 which cleaves GLP-1 from proglucagon in $\alpha$-cells [17]. In both cases, increased GLP-1 production in islet cells was accompanied by increased insulin secretion, enhanced survival in response to cytokine treatment, and protection against $\mathrm{H}_{2} \mathrm{O}_{2}$-induced stress. Transplantation of GLP-1-expressing mouse islets under the kidney capsule of syngeneic diabetic mice allowed a return to normoglycemia in $88 \%$ of treated animals compared to $52 \%$ of animals that had received unmodified islets [18]. Transgenic mice expressing activated M3R at the $\beta$-cell level have been produced [19]. These mice exhibited improved glucose tolerance and increased serum insulin levels. In vitro, islets isolated from these mice showed greater insulin secretion compared to wild-type islets. Inducing these genetic modifications in a novel pig model will be targeted to pancreatic beta cells by adding a porcine insulin promoter to the construct used to transfect primary fibroblasts. In addition, targeting the expression cassette towards a safe-harbor site within the pig genome using specific transcription activator-like effector nuclease (TALEN) pairs should permit to obtain a single integration and stable expression of the desired transgenes.

\section{Modification of Donor Pigs to Mitigate the Immune}

Response Immediately after transplantation to human or non-human primate recipients, porcine islets are subjected to hyperacute rejection due to anti- $\alpha \mathrm{Gal}$ (galactose $\alpha 1,3$ galactose) preformed antibodies binding to the $\alpha \mathrm{Gal}$ oligosaccharide epitope expressed on porcine cells followed by complement activation and neutrophil infiltration. This humoral reaction is even stronger against islets from neonatal pigs since they show higher expression of the $\alpha \mathrm{Gal}$ epitope compared to adult pigs [20]. A major breakthrough in this field was the knockout of both alleles of the $\alpha 1,3$-galactosyltransferase enzyme (GGTA1) which synthesizes the $\alpha$ Gal epitope

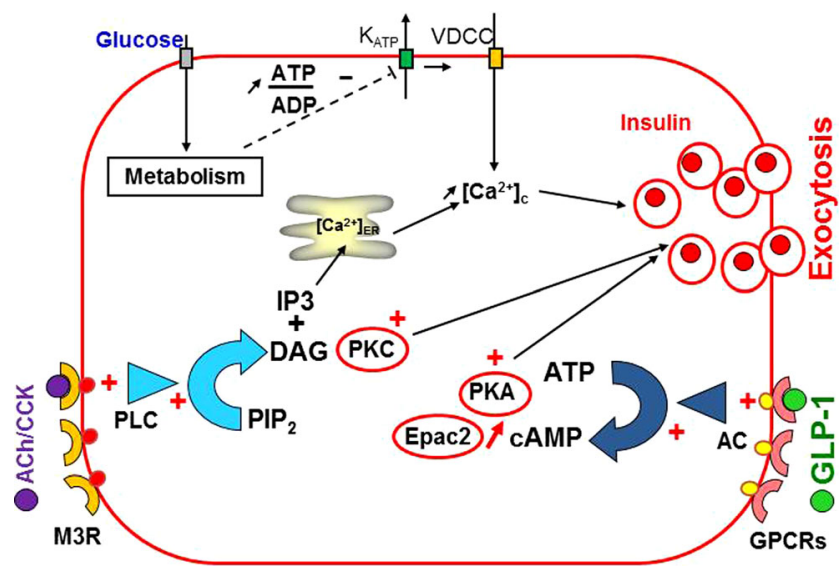

Fig. 2 Triggering and amplifying mechanisms of insulin secretion in pancreatic beta cells. Glucose metabolism increases the ATP/ADP ratio in beta cells. This leads to closure of ATP-dependent potassium channels $\left(K_{A T P}\right)$ and depolarization of the plasma membrane which in turn causes opening of voltage-dependent calcium channels $(V D C C)$, thus allowing entry of calcium and increase of cytosolic calcium concentration $\left(\left[\mathrm{Ca}^{2+}\right] c\right)$. This rise in $\left[\mathrm{Ca}^{2+}\right] \mathrm{c}$ triggers insulin granule exocytosis. Insulin secretion can be further amplified by glucagon-like peptide 1 (GLP-1) binding to its G-protein-coupled receptor $(G P C R)$ and activation of adenylyl cyclase $(A C)$ which converts ATP to cAMP. The rise of cytosolic cAMP then activates protein kinase $\mathrm{A}(P K A)$ and exchange protein activated by cAMP (Epac2). Activation of a type-3 muscarinic receptor $(M 3 R)$ by acetylcholine $(A C h)$ or cholecystokinin $(C C K)$ activates phospholipase $\mathrm{C}(P L C)$ which hydrolyzes phosphatidylinositol-4, 5-bisphosphate $\left(P I P_{2}\right)$ into the protein kinase $\mathrm{C}$ activator $(P K C)$ diacylglycerol $(D A G)$ and inositol trisphosphate (IP3) which mobilizes intracellular calcium stores

resulting in the first transgenic pigs lacking this major xenoantigen [21]. Compared to wild-type islets, GGTA1-KO neonatal islets showed superior secretory function after hepatic transplantation to diabetic immunosuppressed macaques and were less susceptible to complement-mediated destruction in vitro [7]. More recently, double knockout of GGTA1 and of $\mathrm{CMAH}$ (cytidine monophosphate- $N$-acetylneuraminic hydroxylase) responsible for Neu5Gc ( $N$-glycolylneuraminic acid) synthesis was shown to further decrease porcine islet antigenicity compared to GGTA1 knockout alone [22]. A recent paper by Salama et al. showed that such a double knockout in porcine beta cells is possible without affecting islet function both in vivo and in vitro [23]. Another porcine carbohydrate antigen produced by beta-1, 4- $\mathrm{N}$-acetyl-galactosaminyl transferase 2 (B4GALNT2) was identified by screening cDNA from $\mathrm{GGTA}^{-/-}$pig endothelial cells with sera from primates that had rejected GGTA1 ${ }^{-/-}$pig hearts $[24,25]$. Expression of B4GALNT2 in human cells significantly increased antibodydependent complement-mediated lysis when these cells were challenged with serum from pig-to-baboon cardiac xenotransplantation sensitized recipient serum [25] while its deletion in pig PBMCs efficiently reduced human IgG and IgM binding and decreased human anti-porcine cytotoxicity [26, 27]. The fact that a strong humoral response was detected in nonhuman primates receiving alginate-encapsulated islets 
especially against $\alpha \mathrm{Gal}[28,29]$ further emphasizes the necessity to use GGTA1-KO pigs as a background for other genetic modifications. Instant blood-mediated inflammatory reaction (IBMIR) is initiated upon contact between host blood and xenografted tissue. This innate non-specific reaction characterized by thrombin generation and complement activation [30] is caused by tissue factor expression on islets cells [31] and further aggravated by anti-pig antibodies. Encapsulated islets implanted in poorly vascularized sites might escape this reaction at least in the early stages of engraftment but IBMIR causes a quick loss of up to $60 \%$ of islets implanted in the portal vein [32]. Transgenic expression of human CD46 [33•, 34], CD55, and CD59 [35] and knockdown of tissue factor gene [36] were shown to avoid this early damage to the graft by decreasing IBMIR both in vivo and in vitro. hCD46 expression in porcine islets increased graft survival to more than 3 months compared to only 46 days in the case of wild-type islets transplanted to immunosuppressed macaques [34]. Transgenic neonatal porcine islets expressing CD55 and CD59 on a GGTA1-KO background were less susceptible to humoral injury in vitro and did not cause intraportal thrombosis in baboons but suffered from cell-mediated rejection [35]. The impact of tissue factor knockdown in neonatal porcine islets on IBMIR was demonstrated in vitro by treating islets with tissue factor-specific antisense RNA and exposing them to human blood. Reduced clot formation, complement, and coagulation activation were observed with modified islets compared to control islets [36]. In mice, expression of human endothelial protein $\mathrm{C}$ receptor (hEPCR) on islets improved graft survival and function, reduced inflammation and coagulation, and allowed diabetes correction using less islets than required when wild-type mice were used as donors [37]. Antiapoptotic and anti-inflammatory molecules heme oxygenase1 (HO-1) and A20 were shown to be efficient in preserving transgenic porcine endothelial cells against TNF- $\alpha$-induced apoptosis [38, 39]. In islets, expression of HO-1 prolonged pig-to-mouse graft survival and decreased immune cell infiltration and islet cell apoptosis [40]. In the same study, the authors showed that human soluble tumor necrosis factor- $\alpha$ receptor-Fc (sTNF- $\alpha \mathrm{R}-\mathrm{Fc}$ ) expression produced a similar effect but did not protect islet cells against apoptosis during early engraftment period. However, neither sTNF- $\alpha \mathrm{R}-\mathrm{Fc}$ nor HO-1 suppressed anti-pig humoral reaction as attested by antipig IgG and IgM levels 1 month post-implantation [40]. Expression of human leukocyte antigen-E (HLA-E) on porcine endothelial cells decreased natural killer cell-mediated cytotoxicity in vitro and prolonged survival time of pig lungs perfused with human blood ex vivo [41]. Perhaps, the most challenging immunological hurdle to overcome in xenotransplantation is the adaptive immune system's cell-mediated response. Indeed, in most cases, islets that survive early damage due to hyperacute rejection and IBMIR are eventually destroyed by T-cell and macrophage infiltration of the graft
$[42,43,44 \bullet]$. To ensure long-term survival of transplanted islets in non-human primates, severe immunosuppression is necessary [45, 46]. Indeed, without immunosuppression, neonatal porcine islets were destroyed within 4 days following transplantation and this was accompanied by T-cell and macrophage infiltration of the graft site. A CD28-CD154 co-stimulation blockade regimen allowed longer survival of implanted islets and diabetic recipients remained insulinindependent up to 260 days [45]. Comparable results were obtained using adult porcine islets with graft function observed up to 187 days in macaques treated with CD25- and CD154-specific antibodies together with a pretransplant induction therapy using basiliximab and a combination of three drugs for immunosuppression maintenance [46]. However, such aggressive immunosuppressive regimens are not applicable in humans. A much more elegant approach would be to engineer islet cells to produce immunosuppressive antibodies or molecules locally at the graft site, thus preserving the islets and sparing the host from complications of systemic immunosuppression. Pig islets expressing anti-human CD2 [47], porcine cytotoxic $\mathrm{T}$ lymphocyte-associated antigen (pCTLA4) [48], or co-stimulatory signal inhibitor LEA29Y [49] have been described. Whereas transgenic pCTLA4 expression in pigs seemed to compromise their immune system [48], beta cell-specific or ubiquitous LEA29Y expression had no deleterious effect on pig health or reproduction $[49,50]$. Pig-tomouse transplantation of anti-CD2- or LEA29-expressing islets benefited from $\mathrm{CD}^{+}{ }^{+}$T-cell depletion and protection against human peripheral blood mononuclear cells respectively $[47,49]$ but pig-to-primate transplantation of pCTLA4expressing islets did not provide significant amelioration of long-term survival (less than 5 months) [51]. Indeed, comparable survival time was reported in non-human primates implanted with wild-type encapsulated islets without immunosuppression [29]. More recently, microencapsulated neonatal porcine islets were shown to survive and maintain function over a maximal period of 600 days in diabetic patients [8•] suggesting that immunoisolation by cell encapsulation might be a better alternative to prevent cell-mediated rejection and permit long-term survival of transplanted pig islets [52].

\section{Modification of Donor Pigs to Decrease the Risk of} Zoonosis Among porcine microorganisms, porcine endogenous retroviruses (PERVs) are of particular concern as they are encoded within pig DNA and therefore cannot be eliminated by pathogen-free breeding. So far, no evidence for PERV infection in human porcine islet recipients has been reported [53, 54]. However, as in vitro infection of human tumor cell lines and even primary cells has been documented $[55,56]$, current recommendations call for selection of donors with low levels of genomic PERV copies and low PERV expression $[53,57]$. In this context, attempts to reduce or suppress PERV expression by genetic modification of donors 
have been made. Small interfering RNAs have been successfully used to generate transgenic pigs with decreased PERV expression compared to wild-type animals [58, 59] and this inhibitory effect lasted up to 3 years [60]. Zinc finger nuclease-driven knockout of PERV proviral sequences proved to be difficult to achieve since it was accompanied by severe cytotoxicity possibly due to the high number of PERV inserts in the genome [61]. Gene editing using clustered regularly interspaced short palindromic repeat-associated system CRISPR/Cas9 successfully inactivated 62 genomic copies of PERV in a porcine kidney cell line [62•] suggesting that generation of completely PERV-free pigs might be possible. In a recently published study, we analyzed PERV expression in an array of pig tissues with particular emphasis on pancreatic islets [63•]. Although we found PERV expression to be enriched in islet cells and therefore comparable to other non-immune tissues, we could not detect PERV particles or RT activity in islet culture media. This data together with the lack of evidence for PERV infection in human receivers of live porcine tissues might call for reconsideration of the actual risk caused by PERV in the case of islet xenotransplantation although it might be of greater relevance for other tissues.

\section{Neural Xenotransplantation and Gene Therapy}

Neural cell xenotransplantation is an attractive alternative therapy for neurodegenerative diseases affecting neural tissues devoid of complex and precise neuron connections such as the nigrostriatal dopamine neurons involved in Parkinson's disease (PD) [64]. In PD, the aim of cell transplantation is to restore dopamine production in the striatum and reverse impairments in motor behavior. Fetal human dopamine neurons were shown to survive and function up to 10 years following transplantation in PD patients $[65,66]$. In a pioneer phase I clinical study, fetal porcine ventral mesencephalic and striatal cells were implanted to patients with PD or Huntington's disease [67]. Despite $30 \%$ of treated patients showing some improvement, very few surviving porcine cells were found in one deceased patient autopsied 7 months post-implantation. Despite immunological privileges of the brain, Tcell-mediated immune rejection of grafted tissue is a major concern in neural cell xenotransplantation [68] and cyclosporine A immunosuppression was not sufficient to protect neural cell xenografts in rats [69, 70]. As an alternative to immunosuppression, transgenic expression of human CTLA4 in porcine neurons inhibited human T lymphocytes proliferation in vitro without affecting normal development after transplantation in rats [71]. Genetic modifications can also enhance transplanted cells' function or even confer new functions. In a primate model of PD, gene therapy by lentiviral expression of glial cell line-derived neurotrophic factor (GDNF) resulted in significant GNDF expression for up to 8 months and reversed motor deficits [72]. Overexpression of VEGF and GNDF in transplanted human umbilical cord blood mononuclear cells (UCB-MCs) successfully improved symptoms of spinal cord injury in rats [73]. As with other porcine tissues, pig neural cell transplantation carries the risk of PERV transmission as discussed earlier. However, no PERV infection was detected in patients transplanted with neural fetal pig cells [74].

\section{Conclusion}

Pancreatic islet xenotransplantation is the most investigated cell xenotransplantation application in both research and clinical settings. This field has benefited from improvement of islet isolation techniques, cell encapsulation, availability of reliable experimental models, and better understanding of risks inherent to pig cell use in humans. Recent advances in genome editing tools allowed production of multi-transgenic pigs with efficient expression of desired genes [41, 51, 75, 76•,77] without causing deleterious effects on islet function $[23,33 \bullet]$. Most if not all of these genetic modifications of donors are aimed to mitigate immune rejection of grafted cells without the need for radical immunosuppression. Physiological incompatibilities between porcine and human islets need to be taken into consideration and genetic modification of pig beta cells aimed to increase insulin secretion are being investigated with promising results [5•]. Combining these genetic engineering strategies with microbiological selection of animals and pathogen-free breeding as well as cell encapsulation techniques is bringing therapeutic islet xenotransplantation closer than ever to widespread application.

\section{Compliance with Ethical Standards}

Conflict of Interest Pierre Gianello and Nizar Mourad declare no conflict of interest.

Human and Animal Rights and Informed Consent All reported studies/experiments with human or animal subjects performed by the authors complied with all applicable ethical standards (including the Helsinki declaration and its amendments, institutional/national research committee standards, and international/national/institutional guidelines).

Open Access This article is distributed under the terms of the Creative Commons Attribution 4.0 International License (http:// creativecommons.org/licenses/by/4.0/), which permits unrestricted use, distribution, and reproduction in any medium, provided you give appropriate credit to the original author(s) and the source, provide a link to the Creative Commons license, and indicate if changes were made. 


\section{References}

Papers of particular interest, published recently, have been highlighted as:

- Of importance

1. van der Windt DJ, Bottino R, Kumar G, Wijkstrom M, Hara H, Ezzelarab M, et al. Clinical islet xenotransplantation: how close are we? Diabetes. 2012;61(12):3046-55. doi:10.2337/db12-0033.

2. Park CG, Bottino R, Hawthorne WJ. Current status of islet xenotransplantation. Int J Surg. 2015;23(Pt B):261-6. doi:10.1016/j.ijsu. 2015.07.703.

3. Salama BF, Korbutt GS. Porcine islet xenografts: a clinical source of ss-cell grafts. Curr Diab Rep. 2017;17(3):14. doi:10.1007/ s11892-017-0846-7.

4. Veriter S, Aouassar N, Beaurin G, Goebbels RM, Gianello P, Dufrane D. Improvement of pig islet function by in vivo pancreatic tissue remodeling: a "human-like" pig islet structure with streptozotocin treatment. Cell Transplant. 2013;22(11):2161-73. doi:10.3727/096368912X657864.

5. Mourad N, Perota A, Xhema D, Galli C, Gianello P. Transgenic expression of glucagon-like peptide 1 (GLP-1) and activated muscarinic receptor (M3R) significantly improves pig islet secretory function. Cell Transplant. 2016; doi:10.3727/ 096368916X693798. This is the first report of a genetic modification aimed to increase porcine islet insulin secretion.

6. Cooper DK, Matsumoto S, Abalovich A, Itoh T, Mourad NI, Gianello PR, et al. Progress in clinical encapsulated islet xenotransplantation. Transplantation. 2016;100(11):2301-8. doi:10.1097/TP. 0000000000001371.

7. Thompson P, Badell IR, Lowe M, Cano J, Song M, Leopardi F, et al. Islet xenotransplantation using gal-deficient neonatal donors improves engraftment and function. Am J Transplant. 2011;11(12): 2593-602. doi:10.1111/j.1600-6143.2011.03720.x.

8. Matsumoto S, Abalovich A, Wechsler C, Wynyard S, Elliott RB. Clinical benefit of islet xenotransplantation for the treatment of type 1 diabetes. EBioMedicine. 2016;12:255-62. doi:10.1016/j.ebiom. 2016.08.034. This publication reports results of the first governement-approved clinical study of encapsulated neonatal porcine islets.

9. Korbutt GS, Elliott JF, Ao Z, Smith DK, Warnock GL, Rajotte RV. Large scale isolation, growth, and function of porcine neonatal islet cells. J Clin Invest. 1996;97(9):2119-29. doi:10.1172/JCI118649.

10. Kelly AC, Steyn LV, Kitzmann JP, Anderson MJ, Mueller KR, Hart NJ, et al. Function and expression of sulfonylurea, adrenergic, and glucagon-like peptide 1 receptors in isolated porcine islets. Xenotransplantation. 2014;21(4):385-91. doi:10.1111/xen.12101.

11. Mourad NI, Nenquin M, Henquin JC. cAMP-mediated and metabolic amplification of insulin secretion are distinct pathways sharing independence of beta-cell microfilaments. Endocrinology. 2012;153(10):4644-54. doi:10.1210/en.2012-1450.

12. Mourad NI, Nenquin M, Henquin JC. Amplification of insulin secretion by acetylcholine or phorbol ester is independent of beta-cell microfilaments and distinct from metabolic amplification. Mol Cell Endocrinol. 2012; doi:10.1016/j.mce.2012.12.002.

13. Henquin JC, Dufrane D, Kerr-Conte J, Nenquin M. Dynamics of glucose-induced insulin secretion in normal human islets. Am $\mathrm{J}$ Physiol Endocrinol Metab. 2015;309(7):E640-50. doi:10.1152/ ajpendo.00251.2015.

14. Henquin JC, Nenquin M. Activators of PKA and Epac distinctly influence insulin secretion and cytosolic $\mathrm{Ca} 2+$ in female mouse islets stimulated by glucose and tolbutamide. Endocrinology. 2014;155(9):3274-87. doi:10.1210/en.2014-1247.
15. Gilon P, Henquin JC. Mechanisms and physiological significance of the cholinergic control of pancreatic beta-cell function. Endocr Rev. 2001;22(5):565-604. doi:10.1210/edrv.22.5.0440.

16. Chae HY, Kang JG, Kim CS, Lee SJ, Lee M, Kang D, et al. Effect of glucagon-like peptide-1 gene expression on graft function in mouse islet transplantation. Transpl Int. 2012;25(2):242-9. doi:10. 1111/j.1432-2277.2011.01394.x.

17. Wideman RD, Yu IL, Webber TD, Verchere CB, Johnson JD, Cheung AT, et al. Improving function and survival of pancreatic islets by endogenous production of glucagon-like peptide 1 (GLP1). Proc Natl Acad Sci U S A. 2006;103(36):13468-73. doi:10. 1073/pnas.0600655103.

18. Chae HY, Lee M, Hwang HJ, Kim HA, Kang JG, Kim CS, et al. Improved transplantation outcome through delivery of DNA encoding secretion signal peptide-linked glucagon-like peptide-1 into mouse islets. Transpl Int. 2013;26(4):443-52. doi:10.1111/tri.12052.

19. Gautam D, Ruiz de Azua I, Li JH, Guettier JM, Heard T, Cui Y, et al. Beneficial metabolic effects caused by persistent activation of beta-cell M3 muscarinic acetylcholine receptors in transgenic mice. Endocrinology. 2010;151(11):5185-94. doi:10. 1210/en.2010-0519.

20. Rayat GR, Rajotte RV, Hering BJ, Binette TM, Korbutt GS. In vitro and in vivo expression of Galalpha- $(1,3) \mathrm{Gal}$ on porcine islet cells is age dependent. J Endocrinol. 2003;177(1):127-35.

21. Phelps CJ, Koike C, Vaught TD, Boone J, Wells KD, Chen SH, et al. Production of alpha 1,3-galactosyltransferase-deficient pigs. Science. 2003;299(5605):411-4. doi:10.1126/science.1078942.

22. Lutz AJ, Li P, Estrada JL, Sidner RA, Chihara RK, Downey SM, et al. Double knockout pigs deficient in N-glycolylneuraminic acid and galactose alpha-1,3-galactose reduce the humoral barrier to xenotransplantation. Xenotransplantation. 2013;20(1):27-35. doi: 10.1111/xen.12019.

23. Salama A, Mosser M, Leveque X, Perota A, Judor JP, Danna C, et al. Neu5Gc and alpha1-3 GAL xenoantigen knockout does not affect glycemia homeostasis and insulin secretion in pigs. Diabetes. 2017; doi:10.2337/db16-1060.

24. Byrne GW, Stalboerger PG, Du Z, Davis TR, McGregor CG. Identification of new carbohydrate and membrane protein antigens in cardiac xenotransplantation. Transplantation. 2011;91(3):28792. doi:10.1097/TP.0b013e318203c27d.

25. Byrne GW, Du Z, Stalboerger P, Kogelberg H, McGregor CG. Cloning and expression of porcine beta $1,4 \mathrm{~N}$ acetylgalactosaminyl transferase encoding a new xenoreactive antigen. Xenotransplantation. 2014;21(6):543-54. doi:10.1111/xen. 12124.

26. Estrada JL, Martens G, Li P, Adams A, Newell KA, Ford ML, et al. Evaluation of human and non-human primate antibody binding to pig cells lacking GGTA1/CMAH/beta4GalNT2 genes. Xenotransplantation. 2015;22(3):194-202. doi:10.1111/xen.12161.

27. Butler JR, Martens GR, Estrada JL, Reyes LM, Ladowski JM, Galli $\mathrm{C}$, et al. Silencing porcine genes significantly reduces human-antipig cytotoxicity profiles: an alternative to direct complement regulation. Transgenic Res. 2016;25(5):751-9. doi:10.1007/s11248016-9958-0.

28. Kobayashi T, Harb G, Rajotte RV, Korbutt GS, Mallett AG, Arefanian $\mathrm{H}$, et al. Immune mechanisms associated with the rejection of encapsulated neonatal porcine islet xenografts. Xenotransplantation. 2006;13(6):547-59. doi:10.1111/j.13993089.2006.00349.x.

29. Dufrane D, Goebbels RM, Gianello P. Alginate macroencapsulation of pig islets allows correction of streptozotocin-induced diabetes in primates up to 6 months without immunosuppression. Transplantation. 2010;90(10):1054-62. doi:10.1097/TP. 0b013e3181f6e267. 
30. Liuwantara D, Chew YV, Favaloro EJ, Hawkes JM, Burns HL, O'Connell PJ, et al. Characterizing the mechanistic pathways of the instant blood-mediated inflammatory reaction in xenogeneic neonatal islet cell transplantation. Transplant Direct. 2016;2(6): e77. doi:10.1097/TXD.0000000000000590.

31. Ji M, Yi S, Smith-Hurst H, Phillips P, Wu J, Hawthorne W, et al. The importance of tissue factor expression by porcine NICC in triggering IBMIR in the xenograft setting. Transplantation. 2011;91(8):841-6. doi:10.1097/TP.0b013e3182106091.

32. Saudek F, Jirak D, Girman P, Herynek V, Dezortova M, Kriz J, et al. Magnetic resonance imaging of pancreatic islets transplanted into the liver in humans. Transplantation. 2010;90(12):1602-6.

33. Wijkstrom M, Bottino R, Iwase H, Hara H, Ekser B, van der Windt $\mathrm{D}$, et al. Glucose metabolism in pigs expressing human genes under an insulin promoter. Xenotransplantation. 2015;22(1):70-9. doi:10. $1111 /$ xen.12145. This study shows that beta-cell-specific genetic modification using an insulin promoter in pigs has no deleterious effect on beta-cell function.

34. van der Windt DJ, Bottino R, Casu A, Campanile N, Smetanka C, $\mathrm{He} \mathrm{J}$, et al. Long-term controlled normoglycemia in diabetic nonhuman primates after transplantation with hCD46 transgenic porcine islets. Am J Transplant. 2009;9(12):2716-26. doi:10.1111/j. 1600-6143.2009.02850.x.

35. Hawthorne WJ, Salvaris EJ, Phillips P, Hawkes J, Liuwantara D, Burns $\mathrm{H}$, et al. Control of IBMIR in neonatal porcine islet xenotransplantation in baboons. Am J Transplant. 2014;14(6):1300-9. doi:10.1111/ajt.12722.

36. Ma X, Ye B, Gao F, Liang Q, Dong Q, Liu Y, et al. Tissue factor knockdown in porcine islets: an effective approach to suppressing the instant blood-mediated inflammatory reaction. Cell Transplant. 2012;21(1):61-71. doi:10.3727/096368911X580563.

37. Gock H, Lee KF, Murray-Segal L, Mysore TB, d'Apice AJ, Salvaris $\mathrm{EJ}$, et al. Human endothelial protein $\mathrm{C}$ receptor overexpression protects intraportal islet grafts in mice. Transplant Proc. 2016;48(6):2200-7. doi:10.1016/j.transproceed.2016.02.080.

38. Petersen B, Ramackers W, Lucas-Hahn A, Lemme E, Hassel P, Queisser AL, et al. Transgenic expression of human heme oxygenase-1 in pigs confers resistance against xenograft rejection during ex vivo perfusion of porcine kidneys. Xenotransplantation. 2011;18(6):355-68. doi:10.1111/j.1399-3089.2011.00674.x.

39. Oropeza M, Petersen B, Carnwath JW, Lucas-Hahn A, Lemme E, Hassel P, et al. Transgenic expression of the human A20 gene in cloned pigs provides protection against apoptotic and inflammatory stimuli. Xenotransplantation. 2009;16(6):522-34. doi:10.1111/j. 1399-3089.2009.00556.x.

40. Yan JJ, Yeom HJ, Jeong JC, Lee JG, Lee EW, Cho B, et al. Beneficial effects of the transgenic expression of human STNFalphaR-Fc and HO-1 on pig-to-mouse islet xenograft survival. Transpl Immunol. 2016;34:25-32. doi:10.1016/j.trim.2016.01.002.

41. Laird CT, Burdorf L, French BM, Kubicki N, Cheng X, Braileanu $\mathrm{G}$ et al. Transgenic expression of human leukocyte antigen-E attenuates GalKO.hCD46 porcine lung xenograft injury. Xenotransplantation. 2017;24(2). doi:10.1111/xen.12294.

42. Poncelet AJ, Denis D, Gianello P. Cellular xenotransplantation. Curr Opin Organ Transplant. 2009;14(2):168-74.

43. Hawthorne WJ, Lew AM, Thomas HE. Genetic strategies to bring islet xenotransplantation to the clinic. Curr Opin Organ Transplant. 2016;21(5):476-83. doi:10.1097/MOT.0000000000000353.

44. Cowan PJ, Ayares D, Wolf E, Cooper DK. First update of the International Xenotransplantation Association consensus statement on conditions for undertaking clinical trials of porcine islet products in type 1 diabetes - chapter $2 \mathrm{~b}$ : genetically modified source pigs. Xenotransplantation. 2016;23(1):32-7. doi:10.1111/xen.12224.

This is a very informative review discussing recent progress in pig islet genetic modifications for xenotransplantation.
45. Cardona K, Korbutt GS, Milas Z, Lyon J, Cano J, Jiang W, et al. Long-term survival of neonatal porcine islets in nonhuman primates by targeting costimulation pathways. Nat Med. 2006;12(3):304-6. doi:10.1038/nm1375.

46. Hering BJ, Wijkstrom M, Graham ML, Hardstedt M, Aasheim TC, Jie T, et al. Prolonged diabetes reversal after intraportal xenotransplantation of wild-type porcine islets in immunosuppressed nonhuman primates. Nat Med. 2006;12(3):301-3. doi:10.1038/nm1369.

47. Brady JL, Sutherland RM, Hancock M, Kitsoulis S, Lahoud MH, Phillips PM, et al. Anti-CD2 producing pig xenografts effect localized depletion of human $\mathrm{T}$ cells in a huSCID model. Xenotransplantation. 2013;20(2):100-9. doi:10.1111/xen.12025.

48. Phelps CJ, Ball SF, Vaught TD, Vance AM, Mendicino M, Monahan JA, et al. Production and characterization of transgenic pigs expressing porcine CTLA4-Ig. Xenotransplantation. 2009;16(6):477-85. doi:10.1111/j.1399-3089.2009.00533.x.

49. Klymiuk N, van Buerck L, Bahr A, Offers M, Kessler B, Wuensch A, et al. Xenografted islet cell clusters from INSLEA29Y transgenic pigs rescue diabetes and prevent immune rejection in humanized mice. Diabetes. 2012;61(6):1527-32. doi:10.2337/db11-1325.

50. Bahr A, Kaser T, Kemter E, Gerner W, Kurome M, Baars W, et al. Ubiquitous LEA29Y expression blocks T cell co-stimulation but permits sexual reproduction in genetically modified pigs. PLoS One. 2016;11(5):e0155676. doi:10.1371/journal.pone.0155676.

51. Bottino R, Wijkstrom M, van der Windt DJ, Hara H, Ezzelarab M, Murase N, et al. Pig-to-monkey islet xenotransplantation using multi-transgenic pigs. Am J Transplant. 2014;14(10):2275-87. doi:10.1111/ajt.12868.

52. Gianello P, Mourad NI, Cozzi E. Immunoisolation of human or xenogeneic insulin-producing cells: the next step for treating patients with type 1 diabetes? Transplantation. 2016;100(8):1592-4. doi:10.1097/TP.0000000000001374.

53. Denner J, Tonjes RR, Takeuchi Y, Fishman J, Scobie L. First update of the International Xenotransplantation Association consensus statement on conditions for undertaking clinical trials of porcine islet products in type 1 diabetes - chapter 5: recipient monitoring and response plan for preventing disease transmission. Xenotransplantation. 2016;23(1):53-9. doi:10.1111/xen.12227.

54. Morozov VA, Wynyard S, Matsumoto S, Abalovich A, Denner J, Elliott R. No PERV transmission during a clinical trial of pig islet cell transplantation. Virus Res. 2017;227:34-40. doi:10.1016/j. virusres.2016.08.012.

55. Denner J, Tonjes RR. Infection barriers to successful xenotransplantation focusing on porcine endogenous retroviruses. Clin Microbiol Rev. 2012;25(2):318-43. doi:10.1128/CMR.05011-11.

56. Denner J. Porcine endogenous retrovirus infection of human peripheral blood mononuclear cells. Xenotransplantation. 2015;22(2):151-2. doi:10.1111/xen.12150.

57. Spizzo T, Denner J, Gazda L, Martin M, Nathu D, Scobie L, et al. First update of the International Xenotransplantation Association consensus statement on conditions for undertaking clinical trials of porcine islet products in type 1 diabetes - chapter 2a: source pigs - preventing xenozoonoses. Xenotransplantation. 2016;23(1): 25-31. doi:10.1111/xen.12223.

58. Ramsoondar J, Vaught T, Ball S, Mendicino M, Monahan J, Jobst P, et al. Production of transgenic pigs that express porcine endogenous retrovirus small interfering RNAs. Xenotransplantation. 2009;16(3):164-80. doi:10.1111/j.1399-3089.2009.00525.x.

59. Dieckhoff B, Petersen B, Kues WA, Kurth R, Niemann H, Denner J. Knockdown of porcine endogenous retrovirus (PERV) expression by PERV-specific shRNA in transgenic pigs. Xenotransplantation. 2008;15(1):36-45. doi:10.1111/j.1399-3089. 2008.00442.x.

60. Semaan M, Kaulitz D, Petersen B, Niemann H, Denner J. Longterm effects of PERV-specific RNA interference in transgenic pigs. 
Xenotransplantation. 2012;19(2):112-21. doi:10.1111/j.13993089.2012.00683.x.

61. Semaan M, Ivanusic D, Denner J. Cytotoxic effects during knock out of multiple porcine endogenous retrovirus (PERV) sequences in the pig genome by zinc finger nucleases (ZFN). PLoS One. 2015;10(4):e0122059. doi:10.1371/journal.pone.0122059.

62. Yang L, Guell M, Niu D, George H, Lesha E, Grishin D, et al. Genome-wide inactivation of porcine endogenous retroviruses (PERVs). Science. 2015;350(6264):1101-4. doi:10.1126/science. aad1191. The authors succeeded in inactivating all 62 copies of PERV in a porcine kidney cell line.

63. Mourad NI, Crossan C, Cruikshank V, Scobie L, Gianello P. Characterization of porcine endogenous retrovirus expression in neonatal and adult pig pancreatic islets. Xenotransplantation. 2017; doi:10.1111/xen.12311. This is the first study comparing PERV genome copy number and expression in both neonatal and adult porcine pancreactic islets. The authors found no correlation between PERV expression in islets and in PBMCs.

64. Lindvall O, Bjorklund A. Cell replacement therapy: helping the brain to repair itself. NeuroRx. 2004;1(4):379-81. doi:10.1602/ neurorx.1.4.379.

65. Bjorklund A, Stenevi U. Reconstruction of the nigrostriatal dopamine pathway by intracerebral nigral transplants. Brain Res. 1979;177(3):555-60.

66. Perlow MJ, Freed WJ, Hoffer BJ, Seiger A, Olson L, Wyatt RJ. Brain grafts reduce motor abnormalities produced by destruction of nigrostriatal dopamine system. Science. 1979;204(4393):643-7.

67. Fink JS, Schumacher JM, Ellias SL, Palmer EP, Saint-Hilaire M, Shannon K, et al. Porcine xenografts in Parkinson's disease and Huntington's disease patients: preliminary results. Cell Transplant. 2000;9(2):273-8.

68. Melchior B, Remy S, Nerriere-Daguin V, Heslan JM, Soulillou JP, Brachet P. Temporal analysis of cytokine gene expression during infiltration of porcine neuronal grafts implanted into the rat brain. $\mathrm{J}$ Neurosci Res. 2002;68(3):284-92. doi:10.1002/jnr.10216.

69. Larsson LC, Widner H. Neural tissue xenografting. Scand J Immunol. 2000;52(3):249-56.

70. Bonnamain V, Neveu I, Naveilhan P. Neural stem/progenitor cells as a promising candidate for regenerative therapy of the central nervous system. Front Cell Neurosci. 2012;6:17. doi:10.3389/ fncel.2012.00017.

71. Martin C, Plat M, Nerriere-Daguin V, Coulon F, Uzbekova S, Venturi E, et al. Transgenic expression of CTLA4-Ig by fetal pig neurons for xenotransplantation. Transgenic Res. 2005;14(4):37384. doi:10.1007/s11248-004-7268-4.

72. Kordower JH, Emborg ME, Bloch J, Ma SY, Chu Y, Leventhal L, et al. Neurodegeneration prevented by lentiviral vector delivery of GDNF in primate models of Parkinson's disease. Science. 2000;290(5492):767-73.

73. Mukhamedshina YO, Garanina EE, Masgutova GA, Galieva LR, Sanatova ER, Chelyshev YA, et al. Assessment of glial scar, tissue sparing, behavioral recovery and axonal regeneration following acute transplantation of genetically modified human umbilical cord blood cells in a rat model of spinal cord contusion. PLoS One. 2016;11(3):e0151745. doi:10.1371/journal.pone.0151745.

74. Dinsmore JH, Manhart C, Raineri R, Jacoby DB, Moore A. No evidence for infection of human cells with porcine endogenous retrovirus (PERV) after exposure to porcine fetal neuronal cells. Transplantation. 2000;70(9):1382-9.

75. Chen Y, Stewart JM, Gunthart M, Hawthorne WJ, Salvaris EJ, O'Connell PJ, et al. Xenoantibody response to porcine islet cell transplantation using GTKO, CD55, CD59, and fucosyltransferase multiple transgenic donors. Xenotransplantation. 2014;21(3):24453. doi:10.1111/xen.12091.

76. Fischer K, Kraner-Scheiber S, Petersen B, Rieblinger B, Buermann A, Flisikowska T, et al. Efficient production of multi-modified pigs for xenotransplantation by 'combineering', gene stacking and gene editing. Sci Rep. 2016;6:29081. doi:10.1038/srep29081. This study shows the feasability of introducing up to seven genetic modifications aimed to reduce porcine xenograft rejection in a single animal using co-integration of multiple vectors at a single locus.

77. Harris DG, Quinn KJ, French BM, Schwartz E, Kang E, Dahi S, et al. Meta-analysis of the independent and cumulative effects of multiple genetic modifications on pig lung xenograft performance during ex vivo perfusion with human blood. Xenotransplantation. 2015;22(2):102-11. doi:10.1111/xen.12149. 